\title{
Phase equilibria in the system $\mathrm{Ca}_{4} \mathrm{Al}_{6} \mathrm{O}_{12} \mathrm{SO}_{4}-\mathrm{Ca}_{2} \mathrm{SiO}_{4}-\mathrm{CaSO}_{4}-\mathrm{H}_{2} \mathrm{O}$ referring to the hydration of calcium sulfoaluminate cements
}

\author{
Frank Winnefeld ${ }^{\mathrm{a} *}$, Barbara Lothenbach $^{\mathrm{a}}$ \\ ${ }^{a}$ Empa, Swiss Federal Laboratories for Materials Science and Technology, Switzerland
}

Received: 10 December 2015 / Accepted: 07 January 2016 / Published online: 18 April 2016

(C) The Author(s) 2016. This article is published with open access.

\begin{abstract}
This paper presents thermodynamic calculations of the stable hydrate assemblages in calcium sulfoaluminate cements containing different amounts of ye'elemite, calcium sulfate and belite. The ternary diagrams developed in this paper can be used directly to assess the long-term composition of such calcium sulfoaluminate cements containing belite. The phase diagram was validated using experimental data from literature. The ternary diagrams developed can be used to read out directly the stable hydrate assemblage of calcium sulfoaluminate cements containing belite based on their initial composition.
\end{abstract}

Keywords: Calcium sulfoaluminate cement; Hydration; Thermodynamic modelling; Phase diagram

\section{Introduction}

Calcium sulfoaluminate (CSA) cements are receiving increasing interest worldwide as sustainable construction materials because they release less $\mathrm{CO}_{2}$ during their manufacturing than Portland cement $[1,2]$. The CSA clinker contains besides ye'elimite $\left(\mathrm{C}_{4} \mathrm{~A}_{3} \overline{\mathrm{S}}\right)^{1}$ other phases such as belite, ferrite or calcium aluminates and is generally blended with calcium sulfate.

Several types of CSA cements are on the market. CSA cements with high ye'elimite contents ( $>50$ mass- $\%$ ) are mostly used in combination with Portland cement to manufacture fast-setting, rapid hardening and/or shrinkage compensated construction materials. CSA cements with less ye'elimite (in the order of 25-50 mass-\%) contain significant amounts of belite (30-50 mass-\%) and ferrite (5-20 mass-\%) and are proposed to be a sustainable replacement material for Portland cement.

Plain blends of ye'elimite and calcium sulfate hydrate to ettringite and monosulfate in varying proportions depending on the ratio $C \bar{S} / C_{4} A_{3} \bar{S}$, while microcrystalline aluminium hydroxide is formed as by-product. When belite is present, strätlingite and/or C-S-H phases form as additional hydration products. At high belite contents, also portlandite may be present. Thus the composition of the hydrate assemblage of CSA is highly variable depending on the levels of belite and calcium sulfate present in the system.

In order to assess the stable hydrate assemblages of CSA, thermodynamic equilibrium calculations of the simplified system $\mathrm{C}_{4} \mathrm{~A}_{3} \overline{\mathrm{S}}-\mathrm{C}_{2} \mathrm{~S}-\mathrm{C} \overline{\mathrm{S}}-\mathrm{H}_{2} \mathrm{O}$ were carried out, thus neglecting other phases present in CSA such as $C_{2}(A, F)$ or $C_{12} A_{7}$. The obtained data were transferred into a ternary diagram $C_{4} A_{3} \bar{S}-C_{2} S-C \bar{S}$, to visualise the effect of the relative quantities of ye'elimite, calcium sulfate and belite on the resulting hydrate assemblage and volume of the solid phase. The modelled hydrate assemblages were compared to experimental data from literature to validate the calculations and to verify that near equilibrium conditions have been reached. Also metastable hydrate assemblages were discussed. The comparison was focused on CSA cements poor in $C_{2}(A, F)$ and $C_{12} A_{7}$, as their presence adds a further level of complexity.

\section{Short overview on thermodynamic modelling}

Thermodynamic equilibrium calculations, see recent review articles [3, 4] and references cited therein, predict the composition in a system composed of aqueous, solid and gaseous phases at the temperature and pressure of interest. Thermodynamic calculations are based on the relative stability of the different hydrates and aqueous species using sets of thermodynamic data compiled in thermodynamic databases as e.g. $[5,6]$. Thermodynamic modelling of the composition of hydrated cements can be viewed as a mass balance calculation (based on the composition and amount of reacted anhydrous material) using thermodynamics as an intelligent tool to predict which hydrates are the most stable under the conditions investigated. In cement science thermodynamic calculations are a valuable method to understand hydration mechanisms and phase stabilities. They can help to understand on a chemical level the

*Corresponding author: Frank Winnefeld, frank.winnefeld@empa.ch

${ }^{1}$ Cement notation is used in the document: $\mathrm{A}=\mathrm{Al}_{2} \mathrm{O}_{3}, \mathrm{C}=\mathrm{CaO}, \mathrm{F}=\mathrm{Fe}_{2} \mathrm{O}_{3}, \mathrm{H}=\mathrm{H}_{2} \mathrm{O}, \mathrm{S}=\mathrm{SiO}_{2}, \overline{\mathrm{S}}=\mathrm{SO}_{3}$ 
consequences of factors such as cement composition, hydration, leaching, or temperature on the composition and the properties of a hydrated cementitious system. The stable hydrate phases can be calculated for fully hydrated systems or based on the chemistry of the pore solution. Hydration kinetics can be implemented by restricting the dissolution of the anhydrous phases with time which allows following the changes of solid phases and pore solution chemistry during hydration. Thermodynamic calculations can also be coupled with transport models and codes describing the ingress of fluids, ions or gases into porous materials, and the spatial distribution of phase changes due to the ingress can be calculated and related to the durability of concrete [7]. As precipitation processes can be slow, thermodynamic equilibrium may not always be reached, thus it is important to compare the modelling results with experimental data, e.g. X-ray diffraction, thermogravimetry or pore solution composition. For thermodynamic calculations, a geochemical speciation software (such as GEMS or PhreeqC) is needed for the calculations and an as complete as possible compilation of thermodynamic data for all relevant solid, aqueous and gaseous species as described in more detail in $[3,4]$.

\section{Thermodynamic equilibrium calculations of the system $\mathrm{C}_{4} \mathrm{~A}_{3} \overline{\mathrm{S}}-\mathrm{C}_{2} \mathrm{~S}-\mathrm{C} \overline{\mathrm{S}}-\mathrm{H}_{2} \mathrm{O}$}

The system $\mathrm{CaO}-\mathrm{Al}_{2} \mathrm{O}_{3}-\mathrm{SiO}_{2}-\mathrm{CaSO}_{4}-\mathrm{H}_{2} \mathrm{O}$ and its sub-system $\mathrm{C}_{4} \mathrm{~A}_{3} \overline{\mathrm{S}}-\mathrm{C}_{2} \mathrm{~S}-\mathrm{C} \overline{\mathrm{S}}-\mathrm{H}_{2} \mathrm{O}$ have been previously investigated by various authors, see e.g. [8-13]. The $\mathrm{CaO}-\mathrm{Al}_{2} \mathrm{O}_{3}-\mathrm{SiO}_{2}-\mathrm{CaSO}_{4}{ }^{-}$ $\mathrm{H}_{2} \mathrm{O}$ system was explored using thermodynamic calculations by Damidot et al. [10] using the state of the art database available at that time. They identified 9 different stable hydrate phases, which form 37 possible phases assemblages.

In the present paper the sub-system $\mathrm{C}_{4} \mathrm{~A}_{3} \overline{\mathrm{S}}-\mathrm{C}_{2} \mathrm{~S}-\mathrm{C} \overline{\mathrm{S}}-\mathrm{H}_{2} \mathrm{O}$ was re-calculated using GEMS-PSI software V. $3.3[14,15]$ coupled with the Nagra/PSI Chemical Thermodynamic Data Base [16] and the recent cement-specific CEMDATA14.01 database $[5,13,17,18]$. The stable hydrate assemblages were calculated for a temperature of $20^{\circ} \mathrm{C}$ and a water to solid ratio of 1 in steps of 2 mass-\% for the whole ternary diagram $\mathrm{C}_{4} \mathrm{~A}_{3} \overline{\mathrm{S}}-\mathrm{C}_{2} \mathrm{~S}-\mathrm{C} \overline{\mathrm{S}}$ assuming complete hydration. In order to mimic the $\mathrm{pH}$ present in pore solutions of CSA cements, $0.1 \mathrm{~g} \mathrm{KOH} / 100 \mathrm{~g} \mathrm{CSA}$ were introduced into the system. Concerning AFm-phases, a solid solution between $\mathrm{SO}_{4}-\mathrm{AFm}$ (monosulfate) and hydroxy-AFm $\left(\mathrm{C}_{4} \mathrm{AH}_{13}\right)$ was considered [13]. Siliceous hydrogarnet forms only at long hydration times or at elevated temperatures especially in the presence of iron [19] and its formation was considered in the work of Damidot et al. [10]. In the present calculations its formation was suppressed in the equilibrium calculations due to its very slow formation kinetics. Gibbsite and kaolinite were suppressed as well due to the same reason.

\section{Modelling results}

The results of thermodynamic modelling were summarised in binary and ternary diagrams of ye'elemite, calcium sulfate and belite in order to visualise the main effects of the clinker composition on hydrate assemblage and volume. In a first step, the expected compositions in the binary systems ye'elimite-calcium sulfate and ye'elemite-belite are discussed while in a $2^{\text {nd }}$ step the ternary system is investigated. Finally the calculations are verified against available experimental data and the main general trends within the ternary systems are identified.

\section{a) Subsystem $\mathrm{C}_{4} \mathrm{~A}_{3} \overline{\mathrm{S}}-\mathrm{C} \overline{\mathrm{S}}-\mathrm{H}_{2} \mathrm{O}$}

Figure 1a shows the effect of calcium sulfate on the stable phase assemblages of ye'elimite mixtures. Pure ye'elimite hydrates according to Eq. (1) forming monosulfate and microcrystalline $\mathrm{Al}(\mathrm{OH})_{3}$. In the presence of calcium sulfate, ettringite is formed according to Eq. (2).

$\mathrm{C}_{4} \mathrm{~A}_{3} \overline{\mathrm{S}}+18 \mathrm{H} \rightarrow \mathrm{C}_{3} \mathrm{~A} \cdot \mathrm{CS} \cdot 12 \mathrm{H}+2 \mathrm{AH}_{3}$

$\mathrm{C}_{4} \mathrm{~A}_{3} \overline{\mathrm{S}}+2 \mathrm{C} \overline{\mathrm{S}}+38 \mathrm{H} \rightarrow \mathrm{C}_{3} \mathrm{~A} \cdot 3 \mathrm{C} \overline{\mathrm{S}} \cdot 32 \mathrm{H}+2 \mathrm{AH}_{3}$

In the absence of calcium sulfate, also low amounts of ettringite are predicted to be stable. The reason for this is that "monosulfate" forms a solid solution with OH-AFm $\left(\mathrm{C}_{4} \mathrm{AH}_{13}\right)[20,21]$, such that a part of the sulfate ions is replaced by hydroxide. Thus some sulfate is available to form ettringite according to Eq. (2).

With increasing addition of calcium sulfate the quantity of monosulfate decreases and the amount of ettringite increases. Ettringite content reaches its maximum at a molar ratio of calcium sulfate to ye' elimite of 2 (31/69 by mass). Beyond, monosulfate is no longer present, but instead excess calcium sulfate occurs as gypsum.

\section{b) Subsystem $\mathrm{C}_{4} \mathrm{~A}_{3} \overline{\mathrm{S}}-\mathrm{C}_{2} \mathrm{~S}-\mathrm{H}_{2} \mathrm{O}$}

The stable hydrate assemblages of the subsystem $\mathrm{C}_{4} \mathrm{~A}_{3} \overline{\mathrm{S}}-\mathrm{C}_{2} \mathrm{~S}$ $\mathrm{H}_{2} \mathrm{O}$ are shown in Figure $1 \mathrm{~b}$. With increasing amounts of $\mathrm{C}_{2} \mathrm{~S}$, first strätlingite is formed under consumption of $\mathrm{Al}(\mathrm{OH})_{3}$, see Eq. (3):

$$
\begin{aligned}
& \mathrm{C}_{2} \mathrm{~S}+\mathrm{AH}_{3}+5 \mathrm{H} \rightarrow \mathrm{C}_{2} \mathrm{ASH}_{8} \\
& \mathrm{C}_{2} \mathrm{~S}+\mathrm{C}_{2} \mathrm{ASH}_{8} \rightarrow \mathrm{CSH}_{2}+\mathrm{C}_{3} \mathrm{AH}_{6} \\
& 6 \mathrm{C}_{2} \mathrm{~S}+2 \mathrm{AH}_{3}+10 \mathrm{H}+\mathrm{C}_{6} \mathrm{~A}_{3} \mathrm{~S}_{32} \rightarrow 6 \mathrm{CSH}_{2}+3 \mathrm{C}_{4} \mathrm{~A} \overline{\mathrm{S}} \mathrm{H}_{12}
\end{aligned}
$$

Only in blends with at least 35 mass-\% belite, sufficient calcium oxide is available to bind all $\mathrm{Al}(\mathrm{OH})_{3}$ in strätlingite and to enable the formation of C-S-H according to Eq. (4). The uptake of aluminium in C-S-H $[22,23]$, which is not considered in the present cement database, would extend the stability area of C-S-H to slightly lower belite contents. If more belite is present, the strätlingite content decreases due to dilution. Strätlingite is further destabilised at a belite content of $>60$ mass- $\%$ where sufficient calcium oxide is available to stabilise C-S-H and katoite according to Eq. (4). At very high $\mathrm{C}_{2} \mathrm{~S}$ amounts, when strätlingite is no longer occurring, portlandite appears as a stable phase. 
a)

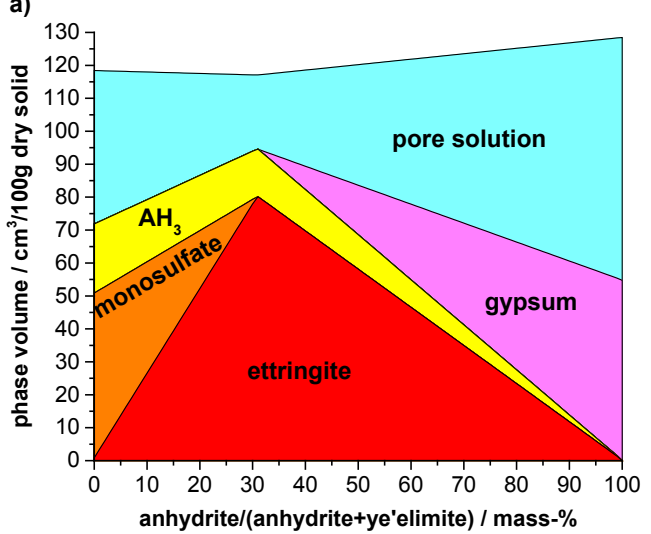

b)

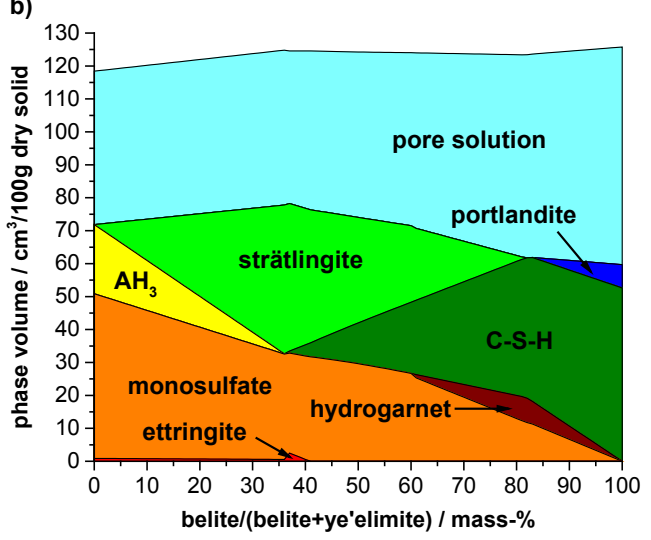

c)

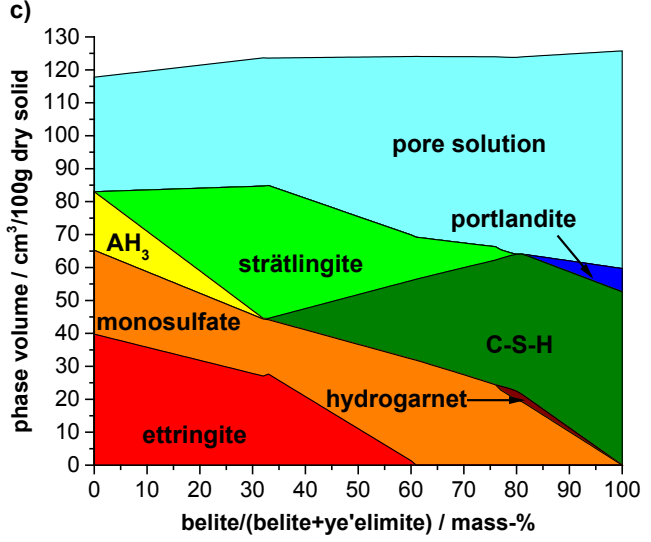

Figure 1. Calculated phase diagram of the thermodynamic stable hydrate assemblages in $\mathrm{cm}^{3}$ per $100 \mathrm{~g}$ of dry solid of a) the system ye'elimite - anhydrite - water, b) the system ye'elimite - belite water, and c) the system ye'elimite - calcium sulfate - belite - water at a fixed molar ratio anhydrite / ye'elimite of 0.8 (anhydrite / ye'elimite $=15: 85$ by mass).

While monosulfate is a stable phase in the entire compositional range (with the exception of hydrated pure $\mathrm{C}_{2} \mathrm{~S}$ ), ettringite, which is occurring in very low amounts, is stable only at ye'elimite contents between 100 and 40 mass- $\%$ and is destabilised to monosulfate if sufficient calcium is available according to Eq. 5. Thus the hydrates in this binary system are determined to a large extent by the availability of calcium oxide.

\section{c) Ternary system $\mathrm{C}_{4} \mathrm{~A}_{3} \overline{\mathrm{S}}-\mathrm{C}_{2} \mathrm{~S}-\mathrm{C} \overline{\mathrm{S}}-\mathrm{H}_{2} \mathrm{O}$}

Figure $1 \mathrm{c}$ presents the phase assemblages for the ternary blend of the anhydrous phases at a fixed value of anhydrite/ye' elimite $=15 / 85$ by mass (molar ratio 0.8 , which is a typical ratio used in non-expansive, high strength CSA cements with high ye'elimite content [2]). The changes in the phase assemblage are similar to the system without calcium sulfate (Figure 1b), but much higher quantities of ettringite and less monosulfate are present. With increasing replacement of ye'elimite by belite, strätlingite forms and $\mathrm{Al}(\mathrm{OH})_{3}$ is consumed as shown also in Figure 1b. Ettringite and strätlingite are no longer stable at replacement levels beyond $60 \%$ and $80 \%$, respectively, while C-S-H and monosulfate are stabilized due to the availability of sufficient calcium oxide from belite according to Eq. (4) and (5). Katoite and portlandite occur beyond approximately 75-80 mass-\% belite.

More trends can be seen if the quantities of the hydrate phases are plotted in a ternary diagram $\mathrm{C}_{4} \mathrm{~A}_{3} \overline{\mathrm{S}}-\mathrm{C}_{2} \mathrm{~S}-\mathrm{C} \overline{\mathrm{S}}$. Figures 2a-c show the amounts of ettringite, $\mathrm{C}-\mathrm{S}-\mathrm{H}$ and strätlingite formed upon complete hydration. The corresponding graphs for monosulfate, katoite, $\mathrm{Al}(\mathrm{OH})_{3}$, portlandite and gypsum are given in the supplementary content. Ettringite (Figure 2a) is stable in almost the entire range of the ternary system with the exception of a small region with high belite contents (above $50 \%$ ) and very low calcium sulfate contents (below 5 mass-\%). Maximum ettringite contents are located around 20-40 mass-\% ye'elimite, 20-40 mass-\% belite and 40-50 mass- $\%$ anhydrite. The presence of belite shifts the area of maximum ettringite formation above the calcium sulfate/ye'elemite ratio of 2 (indicated by the 1:2 line in Figure 2a) as calcium oxide from belite promotes the formation of monosulfate from ettringite and $\mathrm{AH}_{3}$ (Eq. (3) and (5)). C-S-H contents decrease towards lower belite contents (Figure $2 \mathrm{~b}$ ) and $\mathrm{C}-\mathrm{S}-\mathrm{H}$ is absent in the region with both low belite $(<30$ mass-\%) and low anhydrite $(<30$ mass$\%)$ contents. Under these conditions, the silica provided by the belite gets incorporated into strätlingite (Figure 3c). Strätlingite is present only at low anhydrite contents, and does not occur at high belite contents.

The total volume of hydrates (Figure $2 \mathrm{~d}$ ) is strongly related to the amount of ettringite in the hydrate assemblage, as ettringite is the phase incorporating the highest amount of water among the hydrates present in the system.

From Figures 1 and 2 (and the additional graphs in the supplementary content) it is evident, that some phases may coexist in the stable hydrate assemblage and some phases do not coexist with each other. Thus the data was evaluated regarding such compatibilities and incompatibilities, and the results are presented in Table 1 . C-S-H is the only phase compatible with all the other phases. Ettringite does not occur together with katoite, and monosulfate is not stable in the presence of gypsum (or anhydrite) as this combination would react to ettringite. The other main hydrate phases of CSA cements, strätlingite and $\mathrm{Al}(\mathrm{OH})_{3}$ both do not coexist with gypsum or portlandite. 


\section{Comparison to experimental data}

In order to validate the phase diagram (Figure 3), the calculated phase assemblages are compared to data from literature.

The subsystem $\mathrm{C}_{4} \mathrm{~A}_{3} \overline{\mathrm{S}}-\mathrm{C} \overline{\mathrm{S}}-\mathrm{H}_{2} \mathrm{O}$ (see also Figure 1a) is well investigated in literature e.g. by [24-28]. The data by Winnefeld and Barlag [24], who investigated pure ye'elimite and ye'elimite blended with calcium sulfate at molar ratios of $0: 1,1: 1,1: 2,1: 3$ and $1: 4$ at a hydration time of $72 \mathrm{~h}$, fit

a)

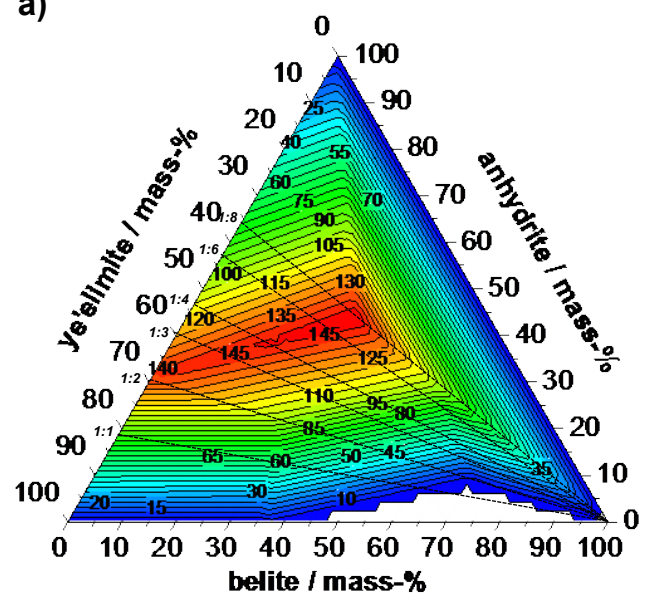

c)

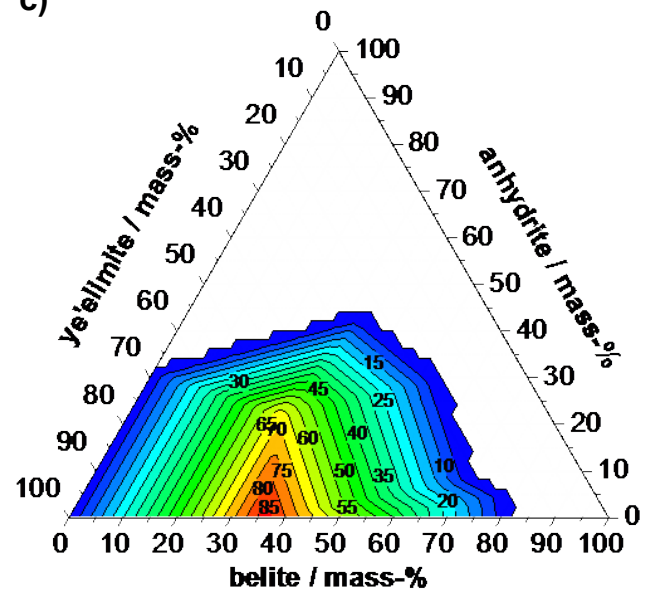

Ettringite $\mathrm{g} / 100 \mathrm{~g}$

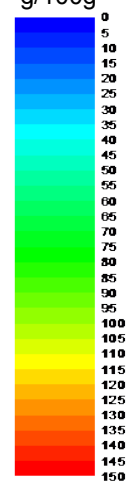

Strätlingite $\mathrm{g} / 100 \mathrm{~g}$

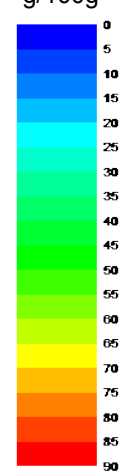

well to the predicted hydrate assemblages. Pure ye'elimite was found to hydrate mainly to monosulfate and $\mathrm{AH}_{3}$ with traces of ettringite present as derived from $\mathrm{X}$-ray diffraction (XRD) and thermogravimetric analysis (TGA). The sample with a molar ratio of 1:1 yielded ettringite and monosulfate besides $\mathrm{Al}(\mathrm{OH})_{3}$, while the samples with $1: 3$ and 1:4 showed the presence of surplus gypsum and the absence of monosulfate. The sample with a molar ratio of 1:2 showed some traces of gypsum, as the reaction of ye' elimite was not complete after $72 \mathrm{~h}$ of hydration.

b)
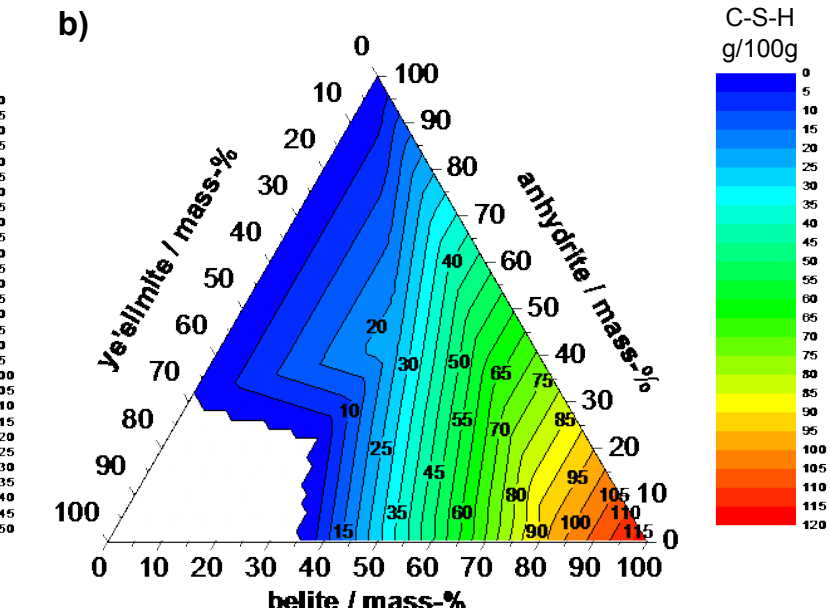

d)

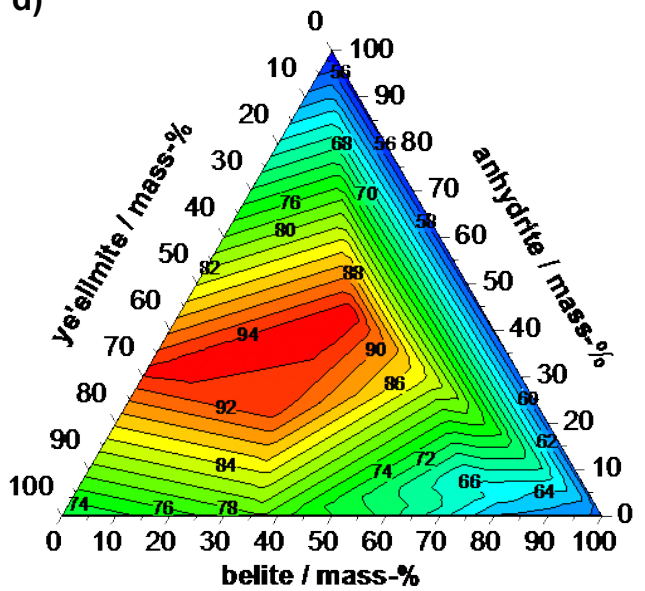

Hydrates $\mathrm{cm}^{3} / 100 \mathrm{~g}$

Figure 2. Ternary diagram $\mathrm{C}_{4} \mathrm{~A}_{3} \overline{\mathrm{S}}-\mathrm{C}_{2} \mathrm{~S}-\mathrm{C} \overline{\mathrm{S}}$ at $20^{\circ} \mathrm{C}$. a) ettringite, b) $\mathrm{C}-\mathrm{S}-\mathrm{H}, \mathrm{c}$ ) strätlingite contents in g per $100 \mathrm{~g}$ unhydrated solid, and d) total volume of hydrates in $\mathrm{cm} 3$ per $100 \mathrm{~g}$ unhydrated solid. The lines in Figure 2a) represent different molar ratios between ye'elimite and anhydrite. The graphs for monosulfate, katoite, aluminium hydroxide, portlandite and gypsum can be found in the supplementary content.

Table 1. Phase compatibility of the stable hydrates in the system $\mathrm{C}_{4} \mathrm{~A}_{3} \overline{\mathrm{S}}-\mathrm{C}_{2} \mathrm{~S}-\mathrm{C} \overline{\mathrm{S}}-\mathrm{H}_{2} \mathrm{O}$

\begin{tabular}{|c|c|c|c|c|c|c|c|c|}
\hline & Ettringite & Monosulfate & Katoite & $\mathrm{AH}_{3}$ & $\mathrm{C}-\mathrm{S}-\mathrm{H}$ & Strätlingite & Portlandite & Gypsum \\
\hline Ettringite & & + & - & + & + & + & + \\
\hline Monosulfate & + & & + & + & + & + & + \\
\hline Katoite & - & + & + & + & + & + & + \\
\hline $\mathrm{AH}_{3}$ & + & + & - & + & + & + & + \\
\hline $\mathrm{C}-S-\mathrm{H}$ & + & + & + & + & + & + & + \\
\hline Strätlingite & + & + & + & + & + & + \\
\hline Portlandite & + & + & + & - & + & - & + \\
\hline Gypsum & + & - & - & - & + & - & + \\
\hline
\end{tabular}



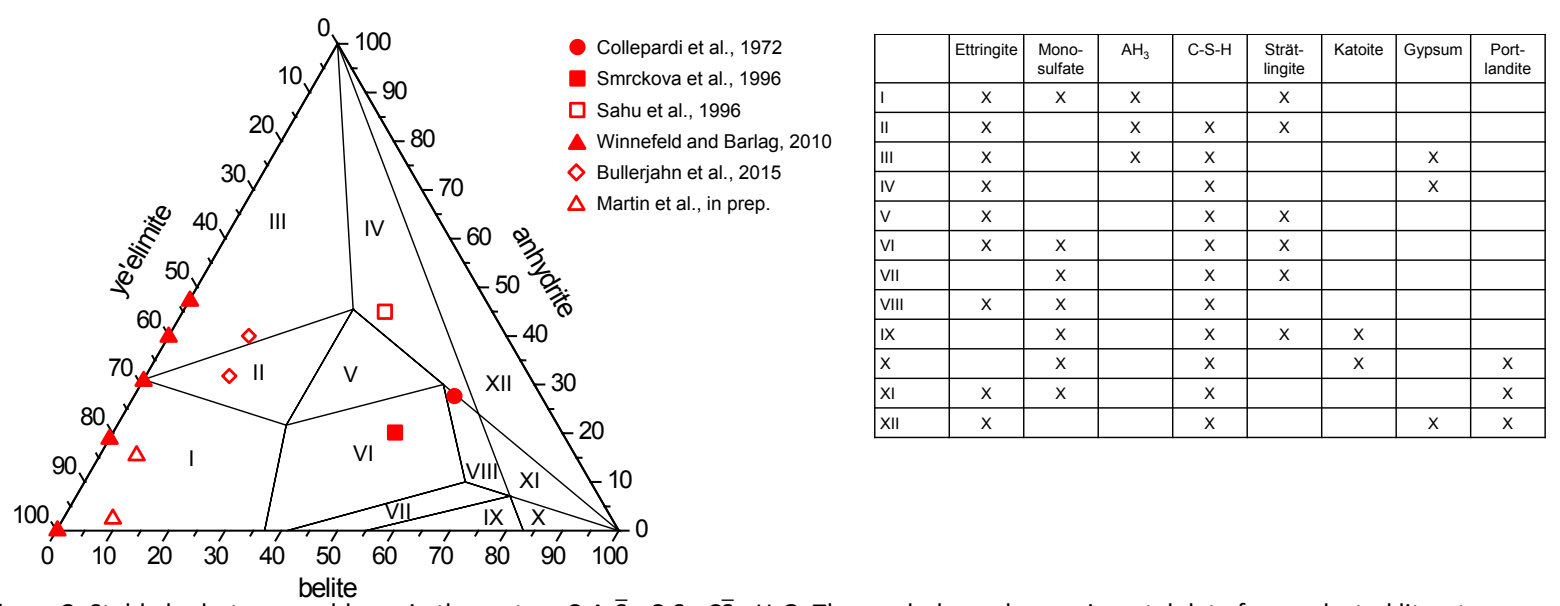

Figure 3. Stable hydrate assemblages in the system $\mathrm{C}_{4} \mathrm{~A}_{3} \overline{\mathrm{S}}-\mathrm{C}_{2} \mathrm{~S}-\mathrm{C} \overline{\mathrm{S}}-\mathrm{H}_{2} \mathrm{O}$. The symbols mark experimental data from selected literature references.

In the ternary system $\mathrm{C}_{4} \mathrm{~A}_{3} \overline{\mathrm{S}}-\mathrm{C}_{2} \mathrm{~S}-\mathrm{C} \overline{\mathrm{S}}-\mathrm{H}_{2} \mathrm{O}$ several datasets are shown in Figure 3 , which were obtained either on pure phases $[8,9,11]$ or on commercial CSA cements [29, 30]. The reaction degrees of the clinker phases and of the calcium sulfate added were considered as far as reported.

Smrckova et al. [11] studied the hydration of a blend of 30 mass-\% ye'elimite, 50 mass- $\%$ belite and 20 mass- $\%$ anhydrite. They performed XRD only after $24 \mathrm{~h}$ of hydration, where hydration especially of the belite was quite incomplete. Thus they identified ettringite as only crystalline phase. Upon complete hydration, some monosulfate and strätlingite could be expected. Sahu et al. [9] investigated a system with much more anhydrite (20\% ye'elimite, $45 \%$ belite and $35 \%$ anhydrite). They observed ettringite and some traces of gypsum, which agrees with the predicted phase assemblage. Besides, also $\mathrm{C}-\mathrm{S}-\mathrm{H}$ should be present. The phase assemblage investigated by Collepardi et al. [8] with 16 mass-\% ye'elimite, 55 mass-\% belite and 29 mass-\% anhydrite is located in the ternary diagram close to the phase assemblages No. IV, V, VI, VIII and XII. Experimentally they found ettringite and a small quantity of monosulfate, while some unreacted calcium sulfate was still present. Their results thus fit to phase assemblage No. VIII (additional C-S-H present), however the presence of some additional strätlingite (phase assemblage $\mathrm{VI}$ ), which might be difficult to detect, cannot be excluded.

The hydration of a ye'elimite-rich CSA cement without and with the addition of anhydrite was investigated by Martin et al. [29] using a water/cement ratio of 0.75 . Both systems are located in the region of the phase assemblage No. I, considering a full hydration of ye'elimite and calcium sulfate, and reaction degrees of belite and bredigite of approximately $35 \%$ after $300 \mathrm{~d}$ of hydration. Ettringite, monosulfate, strätlingite and aluminium hydroxide are predicted as stable phases, which is in agreement with the experimental observations. In the sample without anhydrite added also traces of $\mathrm{CAH}_{10}$ are present after $300 \mathrm{~d}$. Such metastability issues will be discussed later.
Various CSA cements with higher belite contents were investigated by Bullerjahn et al. [30] hydrated for $48 \mathrm{~h}$ using a water/cement ratio of 0.70 . Two examples are included in Figure 2, taking into account their determined reaction degrees. Their clinker MM3 with 35.0 mass-\% ye'elimite, 46.1 mass-\% belite and 4.5 mass- $\%$ anhydrite was blended with 15 mass-\% anhydrite. This system is located in the area of phase assemblage No. II. Experimentally the authors identified ettringite, strätlingite and a high content of amorphous phases by XRD and aluminium hydroxide by TGA, which agrees with the predicted hydrate assemblage. $\mathrm{C}-\mathrm{S}-\mathrm{H}$, which should be present according to the thermodynamic calculations, was not identified due to its poorly crystalline nature. In clinker LH5 (22.0 mass-\% ye'elimite, 63.2 mass-\% belite, 6.5 mass-\% anhydrite) blended with 15 mass-\% anhydrite, ettringite together with aluminium hydroxide as part of the amorphous hydrates was identified in agreement to phase assemblage No. III. As expected from Figure 3, strätlingite was not identified. C-S-H should be present as well, but could not be identified with the methods used.

\section{Metastability issues}

Thermodynamic modelling gives the stable hydrates, neglecting metastable phase assemblages. Therefore, the calculated hydrate assemblages should be crosschecked by experimental data as shown above in order to validate the modelling approach and to identify possible metastable phase assemblages. In the investigated system metastable $\mathrm{CAH}_{10}$ is reported to occur especially in systems with a low ratio of anhydrite to ye'elimite [31, 32], such as plain CSA clinker. Figure 4 shows as an example the development of the crystalline phases upon hydration of a CSA clinker (unpublished data from [29]). $\mathrm{CAH}_{10}$ forms mainly between 1 and 3 days of hydration, and starts to decompose beyond 28 days. 


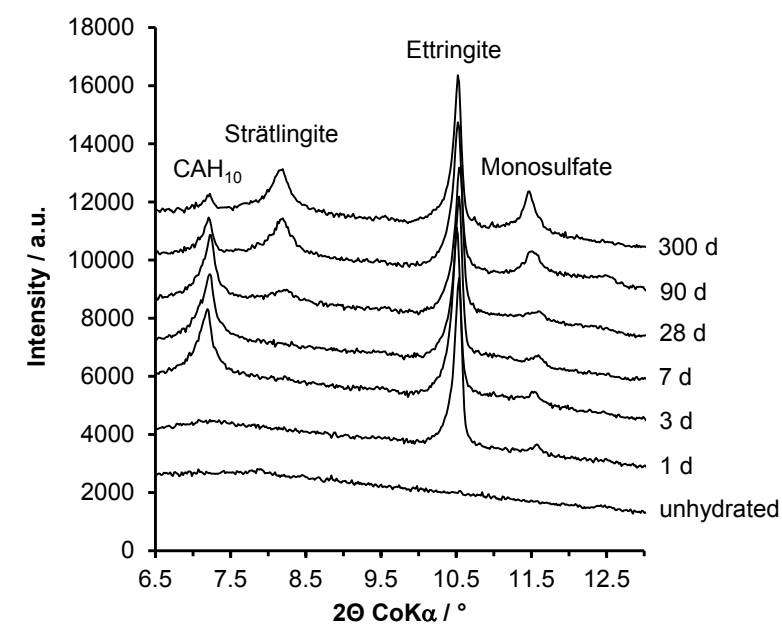

Figure 4. X-ray diffraction patterns of the CSA clinker used in study [29] (unpublished data) depending on hydration time $(w / c=0.75)$.

$\mathrm{CAH}_{10}$ may either form as an intermediate product upon hydration of calcium aluminates such as $\mathrm{CA}$ or $\mathrm{CA}_{2}$ present in the CSA clinker or form directly from the hydration of ye'elimite together with ettringite and aluminium hydroxide according to:

$3 \mathrm{C}_{4} \mathrm{~A}_{3} \overline{\mathrm{S}}+98 \mathrm{H} \rightarrow \mathrm{C}_{3} \mathrm{~A} \cdot 3 \mathrm{C} \overline{\mathrm{S}} \cdot 32 \mathrm{H}+6 \mathrm{CAH}_{10}+2 \mathrm{AH}_{3}$

Sensitivity calculations in GEMS revealed that the formation of monosulfate according to Eq. (1) is thermodynamically favoured over the formation of $\mathrm{CAH}_{10}$ and ettringite according to Eq. (6). However, like in the case of calcium aluminate cements [33], the occurrence of $\mathrm{CAH}_{10}$ is linked to the solubility of microcrystalline $\mathrm{AH}_{3}$, which decreases with time due to an increase of its crystallinity. By increasing the solubility product of microcrystalline $\mathrm{AH}_{3}$ already by $0.3 \mathrm{log}$ units, reaction (6) occurs instead of reaction (1), which indicates only a low energetic difference between both reaction paths. Like in calcium aluminate cements, $\mathrm{CAH}_{10}$ undergoes a conversion at later hydration times which is related to a volume decrease (volume reduction of $34 \%$ between the solid phases in reaction (6) and reaction (1)).

\section{Conclusions}

The stable hydrate phases in the ternary system ye'elimite belite - calcium sulfate, which are relevant for calcium sulfoaluminate cements, were calculated by thermodynamic modelling and visualised in ternary diagrams. As stable hydrate phases in the system $\mathrm{C}_{4} \mathrm{~A}_{3} \overline{\mathrm{S}}-\mathrm{C}_{2} \mathrm{~S}-\mathrm{C} \overline{\mathrm{S}}-\mathrm{H}_{2} \mathrm{O}$ ettringite, monosulfate, strätlingite, $\mathrm{C}-\mathrm{S}-\mathrm{H}$, katoite, aluminium hydroxide, portlandite and gypsum occur depending on the anhydrous composition. Belite increases the availability of $\mathrm{CaO}$ which leads to the stabilisation of monosulfate and C-S$\mathrm{H}$ instead of $\mathrm{AH}_{3}$, ettringite and strätlingite. As a metastable phase $\mathrm{CAH}_{10}$ may be present especially at low anhydrite content and at early ages. From the modelled data, a phase diagram was derived which can be used to predict the stable phase assemblage of CSA cements. The phase diagram was validated using experimental data from several literature references.

The results presented here clearly show on the example of the calculated phase assemblages in the system $\mathrm{C}_{4} \mathrm{~A}_{3} \overline{\mathrm{S}}-\mathrm{C}_{2} \mathrm{~S}$ $\mathrm{C} \overline{\mathrm{S}}-\mathrm{H}_{2} \mathrm{O}$ the high potential of thermodynamic equilibrium calculations to explain the formation and the coexistence of different hydrates depending on the relative amount of ye'elimite, belite and calcium sulfate present. The ternary diagrams calculated and shown in this paper can also be used directly to assess the long-term composition of such calcium sulfoaluminate cements containing belite. The results of such calculations depend strongly on the quality and completeness of the thermodynamic data for the phases of interest. While reliable data are available for the main hydrates, the development of dedicated models such as models for aluminium uptake in $\mathrm{C}-\mathrm{S}-\mathrm{H}$ or an adequate description of the formation kinetics of siliceous hydrogarnet may somewhat modify the diagrams presented in this paper.

\section{References}

[1] E. Gartner, Industrially interesting approaches to "low- $\mathrm{CO}_{2}$ " cements. Cem Concr Res (2004) 34: 1489-1498.

[2] M.C.G. Juenger, F. Winnefeld, J.L. Provis, J.H. Ideker, Advances in alternative cementitious binders. Cem Concr Res (2011) 41: 12321243.

[3] B. Lothenbach, Thermodynamic equilibrium calculations in cementitious systems. Mater Struct (2010) 43: 1413-1433.

[4] D. Damidot, B. Lothenbach, D. Herfort, F.P. Glasser, Thermodynamics and cement science. Cem Concr Res (2011) 41: 679-695.

[5] B. Lothenbach, T. Matschei, G. Möschner, F.P. Glasser, Thermodynamic modelling of the effect of temperature on the hydration and porosity of Portland cement. Cem Concr Res (2008) 38: 1-18.

[6] P. Blanc, X. Bourbon, A. Lassin, E.C. Gaucher, Chemical model for cement-based materials: Thermodynamic data assessment for phases other than C-S-H. Cem Concr Res (2010) 40: 1360-1374.

[7] F.P. Glasser, J. Marchand, E. Samson, Durability of concrete Degradation phenomena involving detrimental chemical reactions. Cem Concr Res (2008) 38: 226-246.

[8] M. Collepardi, R. Turriziani, A. Marcialis, The paste hydration of $4 \mathrm{CaO} \cdot 3 \mathrm{Al}_{2} \mathrm{O}_{3} \cdot \mathrm{SO}_{3}$ in presence of calcium sulphate, tricalcium silicate and dicalcium silicate. Cem Concr Res (1972) 2: 213-223.

[9] S. Sahu, V. Tomková, J. Majling, J. Havlica, Influence of particle sizes of individual minerals on the hydration processes in the system $\mathrm{C}_{2} \mathrm{~S}$ $\mathrm{C}_{4} \mathrm{~A}_{3} \overline{\mathrm{S}}-\mathrm{C} \overline{\mathrm{S}}$. Cem Concr Res (1993) 23: 693-699.

[10] D. Damidot, F.P. Glasser, Investigation of the $\mathrm{CaO}-\mathrm{Al}_{2} \mathrm{O}_{3}-\mathrm{SiO}_{2}-\mathrm{H}_{2} \mathrm{O}$ system at $25{ }^{\circ} \mathrm{C}$ by thermodynamic calculations. Cem Concr Res (1995) 25: 22-28.

[11] E. Smrčková, M. Palou, V. Tomková, Application of conduction calorimetry for study of the reactivity of $\mathrm{C}_{2} \mathrm{~S}$ in the system $\mathrm{C}_{2} \mathrm{~S}-\mathrm{C}_{4} \mathrm{~A}_{3} \overline{\mathrm{S}}$ CS-H. J Therm Anal Calorim (1996) 46: 597-605.

[12] D. Damidot, S. Barnett, F. Glasser, D. Macphee, Investigation of the $\mathrm{CaO}-\mathrm{Al}_{2} \mathrm{O}_{3}-\mathrm{SiO}_{2}-\mathrm{CaSO}_{4}-\mathrm{CaCO}_{3}-\mathrm{H}_{2} \mathrm{O}$ system at $25^{\circ} \mathrm{C}$ by thermodynamic calculation. Adv Cem Res (2004) 16: 69-76.

[13] T. Matschei, B. Lothenbach, F.P. Glasser, Thermodynamic properties of Portland cement hydrates in the system $\mathrm{CaO}-\mathrm{Al}_{2} \mathrm{O}_{3}-\mathrm{SiO}_{2}-\mathrm{CaSO}_{4}-$ $\mathrm{CaCO}_{3}-\mathrm{H}_{2} \mathrm{O}$. Cem Concr Res (2007) 37: 1379-1410.

[14] T. Wagner, D.A. Kulik, F.F. Hingerl, S.V. Dmytrieva, GEM-Selektor geochemical modeling package: TSolMod library and data interface for multicomponent phase models. Can Mineral (2012) 50: 11731195.

[15] D.A. Kulik et al., GEM-Selektor geochemical modeling package: revised algorithm and GEMS3K numerical kernel for coupled simulation codes. Computat Geosci (2013) 17: 1-24. 
[16] W. Hummel, U. Berner, E. Curti, FJ. Pearson, T. Thoenen, Nagra/PSI Chemical Thermodynamic Database 01/01, Universal Publisher/uPUBLISH.com, USA, also published as Nagra Technical Report NTB 02-16, Wettingen, Switzerland (2002).

[17] B. Lothenbach, F. Winnefeld, Thermodynamic modelling of the hydration of Portland cement. Cem Concr Res (2006) 36: 209-226.

[18] B. Lothenbach, L. Pelletier-Chaignat, F. Winnefeld, Stability in the system $\mathrm{CaO}-\mathrm{Al}_{2} \mathrm{O}_{3}-\mathrm{H}_{2} \mathrm{O}$. Cem Concr Res (2012) 42: 1621-1634.

[19] B.Z. Dilnesa, B. Lothenbach, G. Renaudin, A. Wichser, D. Kulik, Synthesis and characterization of hydrogarnet $\mathrm{Ca}_{3}\left(\mathrm{Al}_{x} \mathrm{Fe}_{1-x}\right)_{2}\left(\mathrm{SiO}_{4}\right)_{y}(\mathrm{OH})_{4(3-y)}$. Cem Concr Res (2014) 59: 96-111.

[20] H. Pöllmann, Syntheses, properties and solid solution of ternary lamellar calcium aluminate hydroxi salts (AFm-phases) containing $\mathrm{SO}_{4}{ }^{2-}, \mathrm{CO}_{3}{ }^{2-}$ and $\mathrm{OH}^{-}$. N Jb für Miner Abh: J Mineral Geochem (2006) 182: 173-181.

[21] T. Matschei, B. Lothenbach, F.P. Glasser, The AFm phase in Portland cement. Cem Concr Res (2007) 37: 118-130.

[22] R.J. Myers, E. L'Hôpital, J.L. Provis, B. Lothenbach, Effect of temperature and aluminium on calcium (alumino)silicate hydrate chemistry under equilibrium conditions. Cem Concr Res (2015) 68: 83-93.

[23] J. Haas, A. Nonat, From C-S-H to C-A-S-H: Experimental study and thermodynamic modelling. Cem Concr Res (2015) 68: 124-138.

[24] F. Winnefeld, S. Barlag, Calorimetric and thermogravimetric study on the influence of calcium sulfate on the hydration of ye'elimite. J Therm Anal Calorim (2010) 101: 949-957.

[25] F. Hanic, I. Kaprálik, A. Gabrisová, Mechanism of hydration reactions in the system $\mathrm{C}_{4} \mathrm{~A}_{3} \overline{\mathrm{S}}-\mathrm{C} \overline{\mathrm{S}}-\mathrm{CaO}-\mathrm{H}_{2} \mathrm{O}$ referred to hydration of sulphoaluminate cements. Cem Concr Res (1989) 19: 671-682.

[26] I. Kaprálik, F. Hanic, Phase relations in the subsystem $\mathrm{C}_{4} \mathrm{~A}_{3} \overline{\mathrm{S}}-\mathrm{C} \overline{\mathrm{S}} \mathrm{H}_{2}-\mathrm{CH}-$ $\mathrm{H}_{2} \mathrm{O}$ of the system $\mathrm{CaO}-\mathrm{Al}_{2} \mathrm{O}_{3}-\mathrm{CS}-\mathrm{H}_{2} \mathrm{O}$ referred to hydration of sulphoaluminate cement. Cem Concr Res (1989) 19: 89-102.

[27] C.W. Hargis, A. Telesca, P.J. Monteiro, Calcium sulfoaluminate (Ye'elimite) hydration in the presence of gypsum, calcite, and vaterite. Cem Concr Res (2014) 65: 15-20.

[28] A. Cuesta, G. Álvarez-Pinazo, S.G. Sanfélix, I. Peral, M.A.G. Aranda, A.G. De la Torre, Hydration mechanisms of two polymorphs of synthetic ye'elimite. Cem Concr Res (2014) 63: 127-136.

[29] L.H.J. Martin, B. Lothenbach, E. Tschopp, C.J. Müller, F. Winnefeld, Influence of fly ash on the hydration of calcium sulfoaluminate cement. Cem Concr Res (2016, submitted).

[30] F. Bullerjahn, M. Zajac, M. Ben Haha, CSA raw mix design: effect on clinker formation and reactivity. Mater Struct (2014) 48: 3895-3911.

[31] S. Berger, C. Cau Dit Coumes, P. Le Bescop, D. Damidot, Hydration of calcium sulfoaluminate cement by a $\mathrm{ZnCl}_{2}$ solution: Investigation at early age. Cem Concr Res (2009) 39: 1180-1187.

[32] F. Winnefeld, S. Barlag, Influence of calcium sulfate and calcium hydroxide on the hydration of calcium sulfoaluminate clinker. ZKG International (2009) 62: 42-53.

[33] B. Lothenbach, Thermodynamic modelling of effect of time and silica on the conversion process. In: C. Fentiman, R. Mangabhai, K. Scrivener, editors. Calcium Aluminates, Proceedings of the International Conference 2014. Avignon, France 2014. 